First publ. in: The impact of climate change on European lakes / ed.: Glen George. (Aquatic ecology series ; 4) - Dordrecht; Heidelberg [u.a.] : Springer, 2010, pp. 311-337 'The original publication is available at www.springerlink.com'

\title{
Regional and Supra-Regional Coherence in Limnological Variables
}

\author{
David M. Livingstone, Rita Adrian, Lauri Arvola, Thorsten Blenckner, \\ Martin T. Dokulil, Renata E. Hari, Glen George, Thomas Jankowski, \\ Marko Järvinen, Eleanor Jennings, Peeter Nõges, Tiina Nõges, \\ Dietmar Straile, and Gesa A. Weyhenmeyer
}

\subsection{Introduction}

Limnologists and water resources managers have traditionally perceived lakes as discrete geographical entities. This has resulted in a tendency for scientific lake studies to concentrate on lakes as individuals, with little connection either to each other or to large-scale driving forces. Since the 1990s, however, a shift in the prevailing paradigm has occurred, with lakes increasingly being seen as responding to regional, rather than local, driving forces (Livingstone, 2008). The seminal work on regional coherence in lake behaviour was that of Magnuson et al. (1990), who showed that many features of lakes within the same region respond coherently to drivers such as climate forcing and catchment processes. From this study it emerged that the degree of coherence among lakes is greatest for those properties most directly affected by climate forcing. Specifically, the physical properties of lakes tend to vary in a more coherent way than their chemical and biological properties (see also Kratz et al., 1998). Further overviews of the topics of coherence and climate-driven variability, focusing mainly on North American lakes, have been given by Magnuson et al. (2006a,b). In this chapter, we will examine the phenomenon of spatial coherence among time-series of some important physical, chemical and biological lake variables at regional and supra-regional scales in Europe. Here, spatial coherence is defined as the degree of correlation between time-series of measurements made simultaneously at different locations (in contrast to temporal coherence, which is defined as the degree of correlation between time-series of measurements made at one location but at different times). The concept of coherence in this context is not well-defined in a mathematical sense. It can be parameterised in various ways: for instance as the mean coefficient of determination $\left(r^{2}\right)$ calculated between all possible lake pairs, or as the mean coefficient of determination calculated between each lake and the mean time-series of all other lakes (e.g., Livingstone and Dokulil, 2001), or

D.M. Livingstone (网)

Eawag, Swiss Federal Institute of Aquatic Science and Technology, Ueberlandstrasse 133, CH-8600 Dübendorf, Switzerland

e-mail: living@eawag.ch

Konstanzer Online-Publikations-System (KOPS)

URN: http://nbn-resolving.delurn:nbn:de:bsz:352-opus-112388

URL: http://kops.ub.uni-konstanz.de/volltexte/2010/11238 
as an intraclass correlation coefficient (e.g., Rusak et al., 1999). Regardless of the parameterisation employed, appropriate methods to remove the effect of daily and annual cycles were used in all examples mentioned in this chapter before computing coherence, so that, for instance, shared seasonal patterns among lakes do not affect the results. In the following, we use the term 'regional' to refer to spatial scales corresponding to a circle of about ten kilometres up to several hundred kilometres in diameter, and the term 'supra-regional' to refer to spatial scales any larger than this.

\subsection{How Is a Climate Signal Transferred to Lakes?}

Of the various ways in which a climate signal can be transferred to a lake, arguably the most important is via its effect on water temperature. The heat balance of a lake (Fig. 17.1) is primarily determined by five heat-exchange processes - three radiative and two non-radiative - that act at, or close to, the lake surface (Edinger et al., 1968; Sweers, 1976). These processes are: the absorption of short-wave solar radiation by the lake; the absorption of long-wave atmospheric radiation by the lake; the emission of long-wave radiation from the lake surface; the exchange of latent heat between the lake surface and the atmosphere due to evaporation and condensation; and the convective exchange of sensible heat between lake surface and atmosphere. These processes involve one essentially astronomically determined variable - clear-sky solar radiation - and four meteorological variables - air temperature, cloud cover, wind speed and relative humidity.

Fig. 17.1 Schematic diagram illustrating the five main heat-exchange processes that determine the heat balance of a lake. The main external variables involved are the essentially astronomically determined variable clear-sky solar radiation (SR), and the meteorological variables cloud cover (CC), air temperature (AT), wind speed (WS) and relative humidity (RH)

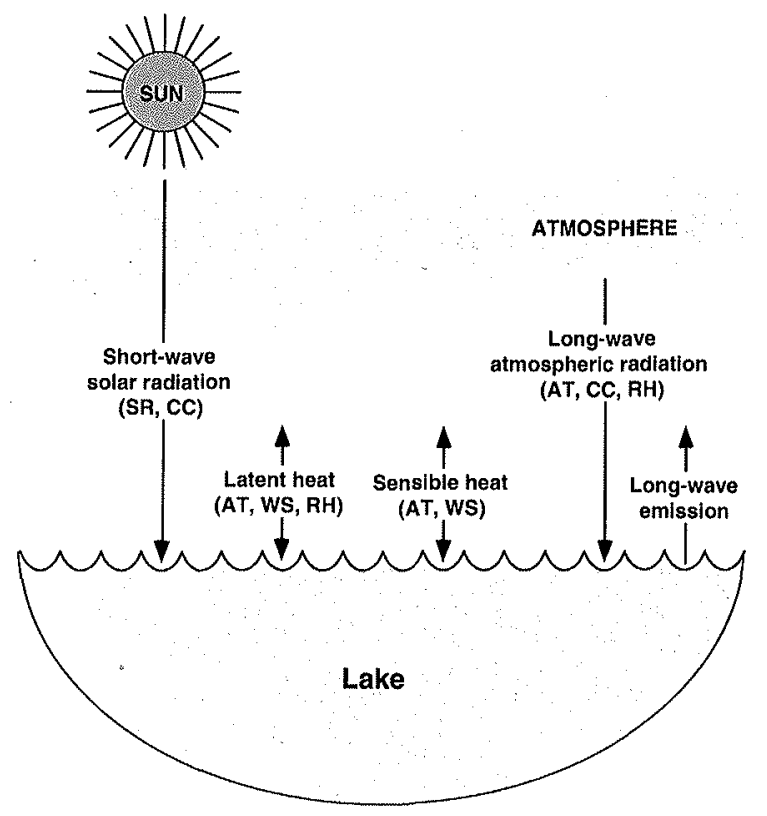


Fig. 17.2 An overview of the factors affecting the relationship between climatic forcing and the physical lake response to this forcing

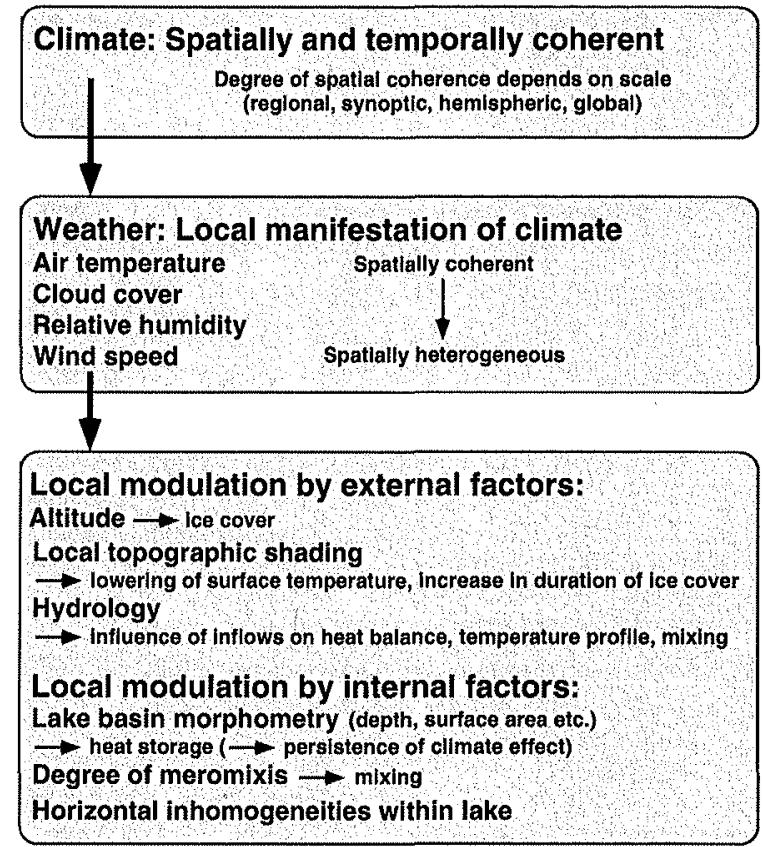

At any given time, the surface water temperature of a lake tends exponentially towards an equilibrium temperature that is defined as the surface water temperature at which the net heat flux into the lake would theoretically be zero (Edinger et al., 1968). The equilibrium temperature is therefore driven by the same five external variables as the lake heat balance. The existence of spatial coherence in any of the five driving variables among the lakes of a given region would thus imply the existence of some degree of spatial coherence in the equilibrium temperatures of the lakes' surfaces, and hence in the lake surface temperatures themselves.

The link between climate forcing and the physical response of a lake to this forcing is illustrated in Fig. 17.2. Although the surface equilibrium temperature of any given lake is ultimately driven by local weather and not large-scale climate, climate and weather are tightly linked conceptually. On the one hand, climate can be viewed as the expression of a high level of spatial and temporal coherence in local weather. On the other hand, weather can be viewed as a local manifestation of climate, implying that local weather is comprised of a large-scale climate signal with superimposed local noise. The signal-to-noise ratio of the climate signal at a lake surface therefore depends on the relative importance of large-scale (e.g., synoptic) and small-scale (local) fluctuations. The individual meteorological variables that comprise the local weather exhibit varying degrees of spatial coherence; i.e., they have differing signalto-noise ratios with respect to the climate signal. Clear-sky solar radiation, the ultimate astronomical driving variable, is responsible for the most obvious spatially coherent fluctuations in lake surface equilibrium temperature, and hence in lake 
surface temperature; viz. the diel and annual cycles. Of the four major meteorological variables that drive the lake surface equilibrium temperature, air temperature is highly spatially coherent (Jones et al., 1997), whereas cloud cover, relative humidity and wind speed are more spatially heterogeneous.

In addition to spatial heterogeneity in local weather, a further source of noise that can mask the climate signal at the lake surface is the modulation of local weather by factors related to lake location. Such factors include altitude and topographic shading, both of which affect lake surface water temperature and the duration of ice cover. They also include the hydrology of the inflows, which can affect the lake heat balance and the form of the temperature profile, and hence the frequency of occurrence and intensity of mixing. In mountainous areas, altitude above sea level can be a very important factor affecting the way lakes respond to climate forcing and the coherence of their response. With increasing altitude, lake surface water temperatures tend to decrease, mainly in response to the approximately linear decrease in surface air temperature (Livingstone et al., 1999, 2005a). In itself this need not necessarily affect the coherence of the physical response of lakes to large-scale climatic forcing; however, at high altitudes, surface water temperature can become increasingly decoupled from ambient surface air temperature, either as a result of a change in lake circulation regime or because of an increased influence of meltwater on the lake heat balance (Livingstone et al., 2005a). Altitude above sea level also determines the duration of ice cover (Eckel, 1955; Livingstone and Dokulil, 2001) and its spatial extent. Additionally, local topographic shading can modify the effects of altitude on lake surface water temperature by depressing it below the value expected due to altitude alone (Livingstone et al., 1999, 2005b; Goudsmit et al., 2000). Snow cover at high altitudes can affect the lake heat balance by feeding the inflow with a constant supply of water close to $0^{\circ} \mathrm{C}$, thus decoupling it to some extent from climatic forcing (Livingstone et al., 2005a). Additionally, local variability in the presence or absence of snow on lake ice can affect water temperatures below the ice by influencing the degree of light penetration (e.g., Schindler et al., 1990). Altitude, topographic shading and local hydrology can thus play important roles in determining the strength of the primary physical response of lakes to climate forcing, and hence the magnitude of climate-related coherence among lakes.

In addition to modulation by external factors, internal factors can also affect the strength of the link between climate forcing and the physical lake response. Lake morphometry influences the distribution of heat, and can also influence the timing of ice-on (Stewart and Haugen, 1990) and the extent of vernal circulation (Salonen et al., 1984). Deep lakes tend to exhibit a more persistent physical response to climatic forcing than shallow lakes (Gerten and Adrian, 2001). The deep waters of lakes which are chemically stratified also tend to respond less sensitively to climatic forcing than the deep waters of lakes which are not (Livingstone, 1993, 1997). Large lakes - especially those with a convoluted coastline and multiple basins, such as the Swedish lakes Mälaren, Vättern and Vänern - can be exposed simultaneously to several different local weather regimes, to which they exhibit an internally heterogeneous response (e.g., Weyhenmeyer, 2004). 
An important question arising from the above is: Are local effects strong enough to destroy the coherence imparted by the climate? If the answer to this question is yes, then surface water bodies are idiosyncratic individuals that merely produce noise, unrelated to any large-scale climate-related forcing. If the answer to this question is no, however, then surface water bodies can be viewed as local samples of a climatically-driven continuum. In the following, we will present evidence to support the latter hypothesis.

\subsection{Short-Term Regional Coherence}

Although lakes respond to local weather on many levels, their most direct response is physical. It is this direct primary physical response of lakes to meteorological forcing that is predominantly responsible for much of the indirect response, since weather-driven variations in the temperature profile, mixing regime and hydrology elicit secondary and tertiary responses at the chemical and biological levels. Thus, any regional coherence among lakes that might be detected on these secondary and tertiary levels is very likely to be the indirect result of coherence in the primary physical response. Because of the time-lags inherent in lake-internal processes, shortterm coherence among lakes (i.e., on time scales of several days or less) is most likely to be detectable in the physical response. This response is strongest in the uppermost levels of the water column, and is most easily detectable in the surface water temperature.

Figure 17.3 illustrates some examples of short-term coherence in lake surface water temperature. Measurements made by Livingstone and Kernan (2009) in 25
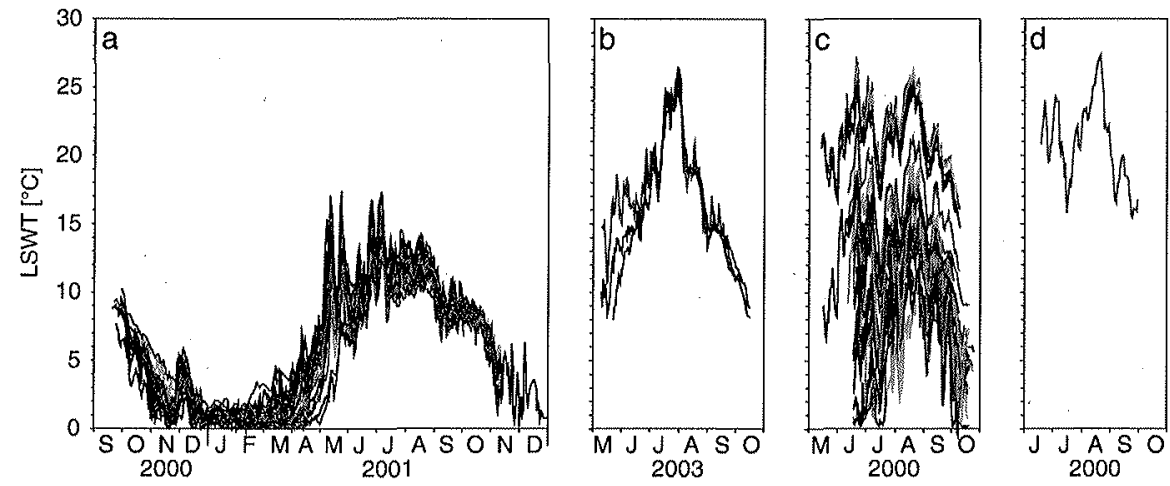

Fig. 17.3 Examples of short-term regional coherence in lake surface water temperature (LSWT). (a) LSWT measured in 25 lochs in the Grampians and the Northwest Highlands of Scotland in 2000 and 2001 (after Livingstone and Kernan, 2009). (b) LSWT measured in Võrtsjärv (Estonia), Peipsi (Estonia) and Pääjärvi (Finland) in 2003 (P. Nõges, T. Nõges, L. Arvola and M. Järvinen, unpublished data). (c) LSWT measured in 29 Swiss lakes in 2000 (after Livingstone et al., 2005a). (d) LSWT measured in Lake Balaton (Hungary) in 2000 (after Livingstone and Padisák, 2007) 
lochs distributed throughout the Grampians and the Northwest Highlands of Scotland (Fig. 17.3a) show regional coherence in surface water temperature to be high during late spring and summer (when the epilimnion is thin), and autumn (when surface water temperatures are determined primarily by surface cooling). Coherence is substantially lower in winter, when fluctuations in lake surface temperature are small and the lochs may be partially ice covered, and in early spring, when they warm up and stratify at different times depending on their altitude and distance from the Atlantic. Measurements in Finland and Estonia show lake surface water temperatures to fluctuate extremely coherently during most of summer and early autumn (Fig. 17.3b). The lake surface temperatures illustrated in Fig. 17.3a,b not only fluctuate coherently within each region, they also differ very little in an absolute sense, making it relatively easy to obtain a reliable estimate of the surface temperatures of other lakes in the region concerned. However, this is only possible because there are no very large differences in altitude among the lakes: the Scottish lochs of Fig. 17.3a all lie within the range $720 \pm 200 \mathrm{~m}$ a.s.l., and the Finnish and Estonian lakes of Fig. 17.3b lie within the range $67 \pm 37 \mathrm{~m}$ a.s.l. In mountainous regions the situation is more complex. In the Swiss Alps below about 2,000 m a.s.l., lake surface water temperatures fluctuate coherently in response to short-term regional climatic forcing, reflecting fluctuations in regional air temperature (Livingstone and Lotter, 1998), but mean lake surface water temperatures decrease approximately linearly with increasing altitude (Livingstone et al., 1999). Figure 17.3c illustrates lake surface water temperatures measured in 29 lakes in Switzerland between $465 \mathrm{~m}$ a.s.l. and $2,470 \mathrm{~m}$ a.s.l. (Livingstone et al., 2005a). The large range of mean values is a result of the pronounced decrease in mean lake surface water temperature that occurs with increasing altitude; however, the degree of short-term coherence in lake surface water temperature among the lakes is still high despite the large differences in altitude. Livingstone et al. (2005b) showed that the pattern of deviations from linearity shown by the surface temperatures of lakes in the Swiss Alps varies little from month to month and from year to year, implying that most local effects do not substantially diminish the short-term coherence of lake surface water temperature, and Livingstone and Hari (2008) demonstrated that the lake surface temperatures of Fig. $17.3 \mathrm{c}$ also fluctuate coherently with river water temperatures throughout Switzerland. For lakes in the Tatra Mountains of Slovakia and Poland, Šporka et al. (2006) confirmed that surface water temperatures respond in a highly coherent fashion to regional climatic forcing, and that they decrease approximately linearly with increasing altitude. However, altitude can also affect the degree of coherence exhibited by lake surface water temperature. Although Livingstone et al. (2005a) showed that the surface water temperatures of lakes in the Swiss Alps respond coherently to regional climatic forcing over an altitude gradient exceeding $2,000 \mathrm{~m}$, they also showed that at altitudes above $\sim 2000 \mathrm{~m}$ a.s.l., the degree of short-term coherence in surface water temperature among the lakes decreases substantially, as does the strength of the relationship between lake surface water temperature and ambient air temperature. This is most likely to be the result either of a difference in the stratification regime at high altitudes, or of an increase in the influence of meltwater on the lake heat budget (Livingstone et al., 2005a). 
Figure 17.3d illustrates the surface water temperature of Lake Balaton, Hungary, during the summer of 2000 ; i.e., during the same period of time as that covered by the measurements of surface water temperature in the Swiss lakes illustrated in Fig. 17.3c. A comparison of Fig. 17.3c with Fig. 17.3d makes it clear that the lake surface water temperatures in Switzerland and Hungary fluctuated coherently during this time (Livingstone and Padisák, 2007). This is perhaps surprising in view of the large distance separating the Swiss and Hungarian lakes $(\sim 750 \mathrm{~km})$ and also in view of the fact that the lakes could hardly be more different in character, Lake Balaton being large $\left(593 \mathrm{~km}^{2}\right)$ and located in the low-lying Carpathian Basin, and the Swiss lakes being smaller by a factor of $10^{3}-10^{5}\left(0.0043-0.46 \mathrm{~km}^{2}\right)$ and located in a mountainous environment, some at altitudes exceeding $2,000 \mathrm{~m}$ a.s.l. Livingstone and Padisák (2007) showed not only that the Swiss and Hungarian lake surface water temperatures fluctuated coherently, they also showed that these fluctuations mirrored fluctuations in the smoothed regional air temperature. This implies that an empirical model based solely on a spatially coherent regional air temperature should suffice to obtain a good estimate of short-term fluctuations in summer lake surface water temperature, even within a large, topographically heterogeneous region. Many studies have suggested methods of predicting lake surface water temperatures from air temperatures (e.g., McCombie, 1959; Webb, 1974; Shuter et al., 1983; Matuszek and Shuter, 1996; Livingstone et al., 1999). More recently, Kettle et al. (2004) have shown that the relationship between lake surface water temperature and air temperature can be improved by applying exponential smoothing to the air temperature. This approach, sometimes including other meteorological variables in addition to air temperature, has been shown to work well in a range of different lake districts, including topographically heterogeneous mountain regions (Kettle et al., 2004; Livingstone et al., 2005a; Šporka et al., 2006; Wilhelm et al., 2006; Livingstone and Padisák, 2007). In such empirical models, air temperature assumes a dual role. Firstly, as a causal variable it is involved explicitly in many of the processes that determine lake surface water temperature. Secondly, it is correlated with the other meteorological variables - viz. wind speed, cloud cover and relative humidity - that co-determine lake surface water temperature.

\subsection{Long-Term Regional Coherence}

Regional-scale coherence among lakes in the long term, here understood to refer to fluctuations on interannual to interdecadal time scales, was first brought to the attention of the limnological community by Magnuson et al. (1990). This study, based on a suite of lakes in Wisconsin, showed that long-term regional coherence was greatest for limnological variables that are directly influenced by climatic factors. Limnological variables that are influenced only indirectly by climate, or by common factors unrelated to climate (such as, for instance, by landscape position), exhibited less coherence. From the beginning therefore, the role of climate as the central factor responsible for long-term regional coherence in limnological variables was clear. 
Further work on the Wisconsin lakes suggested that physical lake variables exhibit a higher degree of long-term regional coherence than chemical variables, which in turn exhibit a higher degree of coherence than biological variables (Kratz et al., 1998; Baines et al., 2000); subsequent work in other regions of the globe has confirmed this, for instance for the English Lake District (George et al., 2000): Here, examples are presented to illustrate the occurrence of long-term regional coherence in a range of physical, chemical and biological variables in selected European lakes and rivers.

\subsubsection{Ice Cover and Water Temperature}

\subsubsection{Ice Phenology in Rivers and Lakes}

Ice phenology - i.e., the timing of ice-on and ice-off - is treated in detail in Chapter 4 of this volume; here, we will simply summarise the information that is most relevant to the topic of long-term coherence. Finland and Sweden have a great number of lakes that consistently freeze over each winter, and for which long series of historical observations on ice phenology exist. In Finland, Palecki and Barry (1986) showed for 63 lakes that the timing of ice-on and ice-off were both highly correlated with air temperature over most of the southern part of the country. Livingstone $(1999,2000)$ showed that much of the coherent variability in the timing of ice-off, in Finland and elsewhere throughout the Northern Hemisphere, is closely related to the air temperature variability associated with the North Atlantic Oscillation (NAO) in winter, which is known to affect large areas not only of Europe, but of the Northern Hemisphere in general (e.g., Hurrell, 1995). Studies by Yoo and D'Odorico (2002), Blenckner et al. (2004) and Magnuson et al. (2004) confirm the importance of the NAO as a major contributor to coherence in ice phenology in northern Europe and elsewhere. Blenckner et al. (2004) found both the timing of ice-on and the timing of ice-off to be coherent among lakes in Finland and Sweden. In addition, they found both not only to be significantly related to the winter NAO, but also, even more strongly, to the regional atmospheric circulation, as represented by a set of regional circulation indices. A study of 196 Swedish lakes by Weyhenmeyer et al. (2004) also demonstrated the high degree of coherence in the timing of ice-off existing among lakes spanning a large latitudinal gradient (from $55^{\circ} \mathrm{N}$ to $68^{\circ} \mathrm{N}$ ) in northern Europe. However, this study also highlighted the importance of including latitude, as a proxy for annual mean air temperature, in any analysis of the coherent response of lake ice phenology to climate forcing. This is not only for the obvious reason that ice-off occurs earlier in warmer, southerly regions than in colder, northerly regions, but, more importantly, because the timing of ice-off responds much more sensitively to air temperature in warmer regions than colder regions.

\subsubsection{River and Stream Water Temperatures}

An analysis of over 35 years of water temperature data from 25 sampling stations on rivers and streams throughout Switzerland, with catchment areas covering a large 


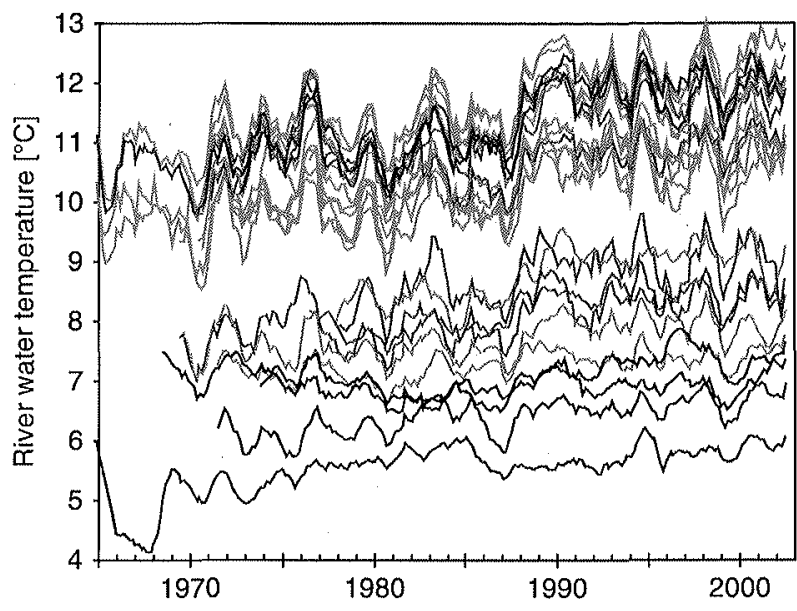

Fig. 17.4 River and stream water temperatures measured in Switzerland from 1965 to 2002 (12-month running means), colour-coded according to mean altitude $\mathrm{h}$ of catchment area: red, $\mathrm{h}<500 \mathrm{~m}$ a.s.l.; orange, $500 \mathrm{~m}$ a.s.l. $\leq \mathrm{h}<1,000 \mathrm{~m}$ a.s.l.; green, $1,000 \mathrm{~m}$ a.s.l. $\leq \mathrm{h}<1500 \mathrm{~m}$ a.s.l.; light blue, 1,500 $\mathrm{m}$ a.s.l. $\leq \mathrm{h}<2,000 \mathrm{~m}$ a.s.l.; dark blue, $\mathrm{h} \geq 2000 \mathrm{~m}$ a.s.l. After Hari et al. (2006)

range of mean altitudes (437-2,395 $\mathrm{m}$ a.s.l.), showed that river water temperatures in all parts of Switzerland exhibit spatially coherent interannual fluctuations (Fig. 17.4; Hari et al., 2006). The existence of this coherence, coupled with the general similarity shown by the temporal structure of the river water temperatures to that of the regional air temperature and the winter NAO (Hari et al., 2006), implies that the river water temperatures exhibit a common response to regional climatic forcing. The climatic factors responsible for the coherent, large step-change in river water temperature from 1987 to 1988 are currently the subject of investigation. The degree of regional coherence in all seasons was found to be particularly high in lower-lying areas and in the foothills of the Alps (i.e., for the higher temperatures shown in Fig. 17.4); however, coherence tends to decrease as the mean altitude of the catchment area of the sampling station increases (i.e., for the lower temperature curves of Fig. 17.4). The study also showed that spatial coherence in water temperature tends to be disproportionately low at sampling points influenced by either glaciers or hydro-electric power stations; this is because both meltwater from glaciers and deep water from reservoirs partially decouple the streams from regional climatic forcing. In the case of streams with partially glaciated catchment areas, inflowing meltwater diminishes the degree of coherence observed in summer and autumn. In their data set, Hari et al. (2006) showed that the three sampling sites with the lowest coherence each have over $14 \%$ glaciers and several hydro-power stations in their catchment areas. The sampling site with the lowest coherence has the highest percentage of glacier cover in its catchment area and the highest hydro-electric power production rate. Generalising from this study, it can be assumed that the water temperatures of rivers and streams are likely to respond coherently to climatic forcing over large areas, except when they are influenced by factors such as glacier 
meltwater, or when the hydrology of the system has undergone anthropogenic alteration.

\subsubsection{Lake Surface Water Temperatures}

Based on unique, 80-year-long time-series of measurements in eight lakes in Austria, Livingstone and Dokulil (2001) demonstrated that a high degree of spatial coherence in lake surface water temperature can exist over several hundred kilometres in all seasons. They showed this to result predominantly from the largescale spatial coherence exhibited by air temperature across the region. In winter and spring, they showed that regional coherence in lake surface water temperature in their data is again ultimately traceable to the winter NAO, whereas in summer the processes responsible are less large-scale in nature. The influence of the winter NAO on the surface and near-surface lake temperatures of lakes throughout Europe has been confirmed in many studies (e.g., George et al., 2000; Straile and Adrian, 2000; Gerten and Adrian, 2001; Straile et al., 2003a,b; Weyhenmeyer, 2004; Blenckner et al., 2007). Despite the strong influence of the NAO on the winter climate, the occurrence of periods of ice cover of various duration was found by Livingstone and Dokulil (2001) to reduce the coherence in lake surface water temperature in winter. This was especially the case for higher-altitude lakes with long periods of ice cover. In spring and summer, the coherence in lake surface water temperature was found to be reinforced by a regional coherence in meteorological driving forces other than air temperature (e.g., wind speed in spring and high-altitude cloud cover in summer).

In northern Europe, Weyhenmeyer (2004) showed that the surface water temperatures of Sweden's largest lakes respond coherently to the winter NAO in March and May, and suggested that this coherent temperature response resulted in coherence being exhibited in various aspects of lake chemistry (see below). In the United Kingdom, surface temperature data from lakes in the English Lake District show a high degree of coherence in all months of the year, with regional coherence being exceptionally high in summer.

\subsubsection{Deep-Water Lake Temperatures}

Not surprisingly, hypolimnetic temperatures are generally much less coherent among lakes than are epilimnetic temperatures (Kratz et al., 1998; Benson et al., $2000)$. Nevertheless, in an analysis of coherence in the response of deep-water temperatures in 12 European lakes to climate forcing, Dokulil et al. (2006) showed regional coherence between lakes to be significant in the majority of cases, with the proportion of shared variance $\left(\mathrm{r}^{2}\right)$ being as much as $89 \%$ between Lake Constance (Austria/Switzerland/Germany) and Walensee (Switzerland), 79\% between Attersee and Hallstättersee (both in the Salzkammergut region of central Austria) and $44 \%$ between Vänern and Vättern (both in, southern Sweden). However, some lakes deviated somewhat from the regional norm: the deep-water temperature of Traunsee, for instance, one of the Austrian Salzkammergut lakes, was more closely correlated 
with the deep-water temperature of very distant lakes, such as Lake Constance and Lake Zurich (300-400 km to the west), and even Vänern (1,250 km to the north), than with that of any of its immediate neighbours. In contrast to lake surface water temperature, which can usually be upscaled without too much problem, one must therefore be extremely cautious in generalising from the behaviour of the deepwater temperature of one lake to that of its immediate neighbours. Coherence in the deep-water temperatures of four deep Swiss lakes was investigated by Livingstone $(1993,1997)$, who showed that, although these temperatures did exhibit a degree of regional coherence, this was greatly affected by the individual characteristics of the lakes. Because deep-water temperatures are influenced primarily by the meteorological conditions prevailing during spring turnover, deep-water temperatures tend to reflect the conditions pertaining during spring rather than integrating the annual climate. This implies that deep-water temperatures in western Europe also tend to be dominated by the NAO (e.g., Straile and Adrian, 2000; Gerten and Adrian, 2001; Straile et al., 2003a, b), although the relationship is more complex than that between the NAO and lake surface water temperature. During summer stratification, deepwater lake temperatures tend to increase gradually at an approximately constant rate as a result of the slow downward transport of heat from the lower metalimnion into the hypolimnion. During winter and spring in open-water lakes, heat loss to the atmosphere at the lake surface coupled with deep, penetrative mixing redistributes the heat in the lake, resulting in a rapid decrease in deep-water temperature. However, during warm winters, stratification can persist from autumn through to spring, inhibiting turbulent mixing and allowing the deep-water temperature to continue its gradual increase without interruption. This eventually results in an irregular sawtooth pattern in the deep-water time-series (Livingstone, 1993, 1997). Although a sawtooth pattern occurs in the deep-water temperature of very many lakes, the exact form of this pattern is critically dependent on individual lake characteristics such as lake depth, exposure to wind and degree of meromixis. Lakes within the same region that are subject to essentially the same climatic forcing can therefore exhibit completely different sawtooth patterns (Livingstone, 1993, 1997). Thus, although a high degree of spatial coherence may be present in the meteorological forcing variables and in lake surface water temperatures, this will not necessarily be the case for deep-water temperatures. Further information on the impacts of climatic variations and climate change on the thermal characteristics of lakes in Europe is given in Chapter 6 of this volume.

\subsubsection{River Discharge Rate and Lake Level}

In contrast to most limnological variables, hydrological variables, such as river discharge rate and lake level, are governed to a much greater extent by precipitation rather than heat balance. The spatial heterogeneity of precipitation is notoriously large in comparison to that of other meteorological variables; it is therefore interesting to note that hydrological variables - which result essentially from the integration 


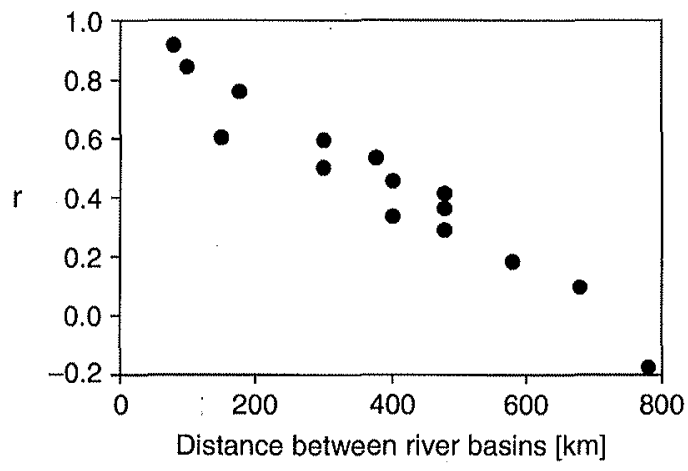

Fig. 17.5 Spatial coherence in monthly mean discharge rates of six rivers in Finland. The plot shows the correlation coefficient ( $r$ ) between monthly mean discharge rates as a function of the distance between the individual river drainage basins. The correlations are based on data for 1961-2002 in the rivers Kokemäenjoki, Aurajoki, Tornionjoki and Kiiminkijoki, and for 1971-2002 and 1984-2002 in the rivers Kalajoki and Pyhäjoki

of precipitation within river drainage basins - can also exhibit a high degree of spatial coherence. A good example of this is provided by Fig. 17.5, which illustrates the spatial coherence found in the monthly mean discharge rates of six rivers in Finland. The geographical locations of the drainage basins of the rivers range from southern boreal to subarctic. Drainage basins separated by less than $\sim 200 \mathrm{~km}$ were found to exhibit an extremely high degree of coherence in their monthly mean discharge rates, but the degree of coherence fell approximately linearly with increasing distance to reach zero at a distance of $\sim 700 \mathrm{~km}$.

In flat landscapes, rates of discharge from lakes are often limited by the low gradients of the outflowing rivers. In such situations, coherent variations in river discharge rates can result in large, coherent variations in lake water level. The example in Fig. 17.6 illustrates the substantial long-term coherence in water level that exists among several large lakes in north-eastern Europe. Since these lakes tend to have extensive shallow littoral areas, vertical variations in lake water level result in large variations in lake volume and in the relative position of the shoreline. In northeastern Europe, coherent fluctuations in lake level can therefore be an important factor influencing lake ecosystems (Nõges et al., 2003; Nõges and Nõges, 2004). In Lake Võrtsjärv, for example, with a surface area of $270 \mathrm{~km}^{2}$ and a mean depth of 2.8 $\mathrm{m}$, the lake level fluctuates seasonally by $1.4 \mathrm{~m}$ on average; i.e., by half the mean depth of the lake. The absolute range of these fluctuations $(3.2 \mathrm{~m})$ even exceeds the lake's mean depth. Between the recorded minimum and maximum water levels, the lake surface area varies by a factor of 1.4, the mean depth by a factor of 2.5 , and the volume by a factor of 3.5. The sensitivity of large lake ecosystems to changes in water level decreases with increasing mean depth. The seasonal and interannual ranges of water level fluctuations in Lake Peipsi are of the same magnitude as those found in Lake Võrtsjärv, but since Lake Peipsi has a much greater mean depth $(7.1 \mathrm{~m})$, water level variations affect this lake much less than they do Lake Võrtsjärv. 


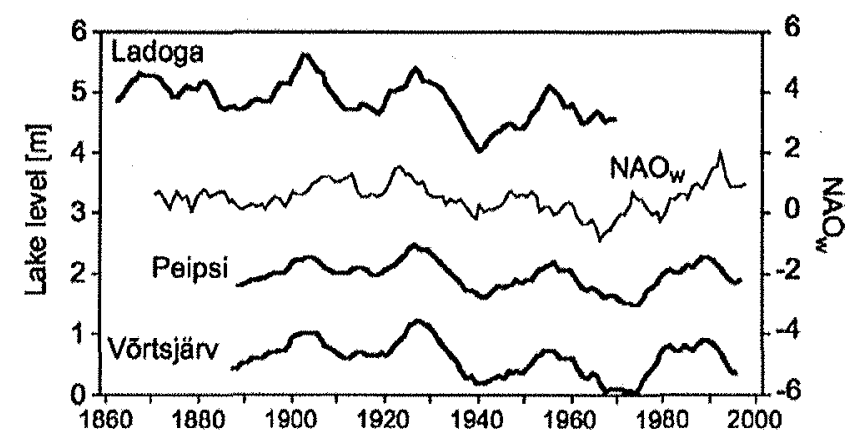

Fig. 17.6 Spatial coherence in annual mean water level of three large lakes in north-eastern Europe. Water level data for Lake Võrtsjärv (Estonia) and Lake Peipsi (Estonia/Russia) were obtained from the Estonian Institute for Meteorology and Hydrology; data for Lake Ladoga (Russia) were taken from Jaani (1973). All series were smoothed with a 7-year moving average. The time-series of the North Atlantic Oscillation index (Hurrell, 1995) is shown for comparison

Winter precipitation in northern Europe is known to be influenced significantly by the winter NAO, with precipitation being above average during a positive phase of the NAO and below average during a negative phase (Hurrell, 1995). Thus it is likely that spatial coherence in river discharge and lake level in this region may ultimately be related to the large-scale influence of the winter NAO. Various studies suggest that the NAO is indeed the driving force behind much of the variability in stream discharge in various regions of Europe. In northern and western Europe, above/below average values of river discharge tend to be associated with positive/negative phases of the winter NAO (e.g., Kiely, 1999; Hänninen et al., 2000; Bradley and Ormerod, 2001). In southern Europe, the situation is the reverse: coherent variations in the discharge rates of the Rhône and the Ebro appear to reflect variations in the winter $\mathrm{NAO}$, with high rates of discharge being associated with the negative phase of the NAO, and low rates of discharge with the positive phase (Lloret et al., 2001). With respect to lake level variations, Rodionov (1994) demonstrated that the water level of the Caspian Sea was related in a more complex way to the $\mathrm{NAO}$ via its effects on precipitation rates in the Volga basin. From Fig. 17.6, it can be seen that longer-term coherent fluctuations in the water levels of Lake Ladoga, Lake Peipsi and Lake Võrtsjärv also appear to reflect the behaviour of the winter NAO. A similar behaviour has been documented for lakes in northern Germany (Behrendt and Stellmacher, 1987) and Russia (Doganovsky and Myakisheva, 2000).

\subsubsection{Lake Chemistry}

Investigations of regional coherence in the chemical properties of lakes have focused mainly on the effects of atmospherically transported pollution, which have been dealt with in great detail in the literature (e.g., Battarbee et al., 2005) and which will thus not be considered further here. Somewhat less attention has been paid 
to regional coherence in lake nutrient concentrations (e.g., George et al., 2004a,b; Weyhenmeyer, 2004), which will therefore form the focus of this section. Some nutrient studies have been based on raw time-series, whilst in others, the data were detrended to remove the effects of progressive alterations in trophic status brought about by large-scale changes in land use or by the simultaneous introduction of measures to counter eutrophication.

The most comprehensive recent investigation of long-term regional coherence in lake chemistry was undertaken by Weyhenmeyer (2004), who studied NAO-related synchrony in the behaviour of 13 chemical variables at 16 sites in Sweden's largest lakes, Vänern, Vättern and Mälaren. She found that coherent relationships between the winter NAO and water chemistry among lake sites were restricted to variables closely linked to surface water temperature, and that the strongest coherent response to climate forcing was exhibited by reactive silica and $\mathrm{pH}$ in May, after the ice on the lakes had thawed. In a comparable study of 28 boreal lakes located within a circle of radius $10 \mathrm{~km}$ in southern Finland, Järvinen et al. (2002) showed interannual coherence to be high for conductivity, calcium and alkalinity (in addition to water temperature). Interannual fluctuations in local weather explained part of the interannual fluctuations in lake chemistry, but pairs of lakes that were directly connected via a surface stream were found to exhibit a higher coherence than pairs of lakes that were not, implying that the presence or absence of hydrological connectivity can affect the interannual coherence of chemical variables. The high coherence found by Järvinen et al. (2002) for calcium agrees with similar results obtained by Baines et al. (2000) for the lakes of northern Wisconsin. Presumably because the winter ice cover effectively insulated the Finnish lakes from climatic forcing, the water chemistry under the ice in March appeared to be associated with the weather conditions prevailing during the previous autumn rather than winter.

Other chemical variables that exhibit a degree of coherence in their behaviour that appears to be linked to the winter NAO include total organic carbon (TOC), oxygen and soluble reactive phosphorus. In a study of the influence of climate and land use on rivers in Finland, Arvola et al. (2004) found TOC loads in spring to respond coherently to the winter NAO in rivers in northern Finland, but not in southern Finland. Investigations into deep-water oxygen concentrations in Swiss lakes have revealed a connection to the suppression of circulation during warm winters (Livingstone, 1997; Straile et al., 2003a), which can also be assumed to be linked to the winter NAO. In the case of phosphorus, coherence seems to be much lower, as does its association with the NAO (e.g., George et al., 2004b). However, there is some evidence suggesting the existence of regionally coherent fluctuations in soluble reactive phosphorus in lakes. Blelham Tarn in the English Lake District is quite a productive lake surrounded by agricultural land, but there has been no recent increase in winter concentrations of soluble reactive phosphorus (Fig. 17.7a). Esthwaite Water, a neighbouring lake, has the added complication of a sewage treatment plant, so the progressive increase in the numbers of tourist visitors to the Lake District has resulted in increasing concentrations of this nutrient (Fig. 17.7b). The time-series of residuals generated by linear detrending (Fig. 17.7c) can be seen to be quite coherent, with $35 \%$ shared variance. The key factor underlying the coherence 

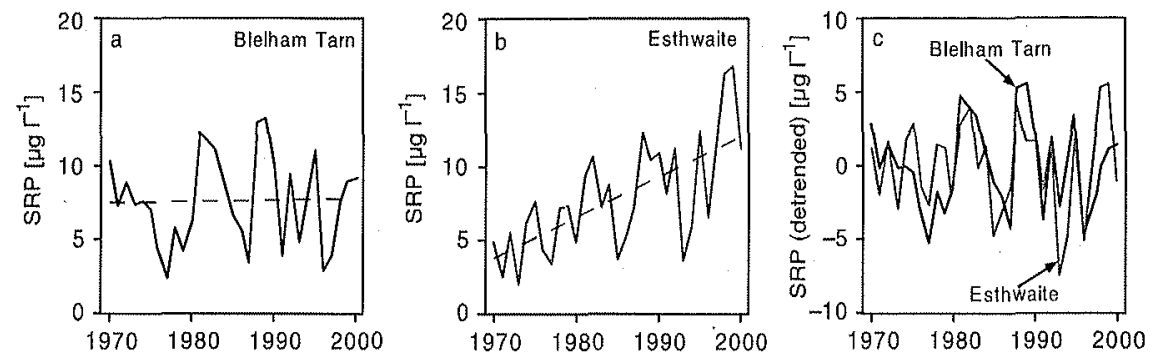

Fig. 17.7 The year-to-year variation in the winter concentration of soluble reactive phosphorus (SRP) in (a) Blelham Tarn and (b) Esthwaite Water, in the English Lake District. The broken lines show the linear regressions used to detrend the two time-series. (c) The year-to-year variation in the detrended SRP time-series for the two lakes

in soluble reactive phosphorus in this case is the interannual variation in winter rainfall. The surface runoff following a heavy rainfall washes soluble reactive phosphorus into lakes from their (unfrozen) catchment areas, which, in the case of lakes with short retention times, results in higher concentrations of this nutrient being recorded (George et al., 2004b). Thus regional coherence in winter rainfall, possibly linked to the winter $\mathrm{NAO}$, will result in regional coherence in winter concentrations of soluble reactive phosphorus in frost-free regions.

However, the chemical constituent that has attracted most attention in European lakes and rivers with regard to interannual coherence is nitrate. Nitrate concentrations in winter and early spring are known to exhibit strongly coherent interannual fluctuations related to winter climate (see Chapter 10 of this volume). In Fennoscandia, for instance, detrended nitrate concentrations in March show a significant positive correlation with the mean air temperature during the previous winter (George et al., 2004a; Weyhenmeyer, 2004). Reasons given for this include a reduction in nitrate release from frozen ground in the catchment area in cold winters (Weyhenmeyer, 2004) and the earlier melting of snow in warm winters (George et al., 2004a). By contrast, in western and central Europe, winter and spring nitrate concentrations in lakes and streams appear to vary inversely with mean winter air temperatures (George, 2000; Monteith et al., 2000; George et al., 2004a,b; Davies et al., 2005; Jankowski et al., 2005). The most likely explanation for this widespread response would seem to be the effect that the severity of the winter has on the terrestrial assimilation of nitrate in the catchment area. The higher denitrification rates of soil bacteria that occur in milder winters, in combination with higher nitrate leaching due to frost damage of biological material in cold winters, may be responsible for the negative correlation of nitrate concentrations with winter air temperature in the UK and Switzerland (Monteith et al., 2000; George et al., 2004a,b; Davies et al., 2005; also see Chapter 10 of this volume). Nitrate leaching is enhanced during cold winters when a greater duration and intensity of soil freezing enhances biocidal effects, releasing more nitrogen for mineralisation, while low soil temperatures may also retard assimilation of nitrogen by soil biota. Not surprisingly, the 
high degree of coherence observed in variations in winter nitrate concentrations can again be traced back to the winter NAO (Monteith et al., 2000, George et al., 2000, 2004a,b). In Ireland, however, the pattern differs from that observed in the UK. Detrended nitrate concentrations in Lough Leane show no significant correlation with the winter NAO (Jennings et al., 2000). A recent analysis shows that interannual fluctuations in nitrate concentrations in Lough Leane and Muckross Lake are related to interannual fluctuations in the position of the Gulf Stream (Jennings and Allott, 2006). This relationship is driven by the effect the position of the Gulf Stream appears to have on moisture levels in catchment soils during the previous summer. Low soil moisture levels inhibit the uptake of nitrogen by plants and soil microbes, leading to higher soil nitrate availability in the autumn and winter, when wetter conditions re-occur (Jennings and Allott, 2006).

Various factors can influence the long-term regional coherence of nitrate concentrations in rivers and lakes. Local geomorphological lake characteristics, such as lake size, the ratio of surface area to mean lake depth or the ratio of lake surface area to catchment area, are likely to modify the effect of climatic forcing on the regional coherence of nitrate. In the central perialpine region, for example, nitrate concentrations in smaller lakes appear to respond more sensitively to climatic forcing than in larger lakes (Jankowski et al., 2005). In addition, Blenckner et al. (2007) suggest that the ratio of surface area to mean lake depth may significantly affect the strength of the climate signal. The strength of the regionally coherent response of nitrate concentration to large-scale climatic forcing factors may also undergo a gradual long-term change that is driven by external forces, such as changes in nitrogen deposition, as in the case of lakes in Sweden (Weyhenmeyer et al., 2007), or the use of fertilisers in lake catchment areas, as in the English Lake District (George et al., 2000). In the English Lake District there appears to be a marked seasonal variability in the regional coherence of nitrate related to climate forcing: although regional coherence in mean nitrate concentration in the Lake District is high in all months, it is highest during winter and spring (Fig. 17.8). This is predominantly a result of the effect of interannual variations in the weather in winter and spring on the leaching of fertilisers applied to the surrounding land. George et al. (2004b) have shown that the concentrations of nitrate reaching the lakes are much lower in

Fig. 17.8 Seasonal variability of the pairwise coefficient of determination $\left(\mathrm{r}^{2}\right)$ of the linearly detrended mean nitrate concentrations in Blelham Tarn, Esthwaite Water and the North and South Basins of Windermere in the English Lake District (means and standard errors) Calculations based on data from 1960-2000

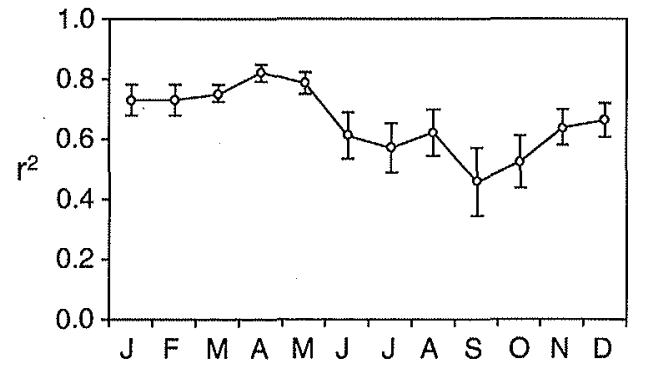


mild winters when there is an enhanced uptake of nitrate in the surrounding land. In summer, the concentrations of nitrate in the lakes are reduced by biological uptake within both the lakes and their catchments, but the residual concentrations present are still quite high, so the effect of coherent fluctuations in nitrate concentrations in winter and spring effectively persists into summer.

\subsubsection{Lake Biology, Population Dynamics and Food Web Interactions}

The degree of coherence observed in most biological time-series is much lower than in physical and chemical time-series because of the multiplicity of confounding factors involved. Nevertheless, coherence studies of biological variables are of value in highlighting common biological responses in lakes exposed to comparable largescale driving forces.

Biological populations in seemingly isolated lacustrine ecosystems may exhibit coherent behaviour if aspects of those elements of the physical environment that regulate their temporal dynamics also exhibit a degree of coherence. Many biological processes in lakes are strongly influenced by physical processes, but the impact of these processes varies from season to season and from lake to lake. In temperate lakes, the physical conditions that prevail during winter and spring differ strongly from those required for optimum growth. Water temperatures are low, resulting in low growth rates of zooplankton, benthos and fish. The low solar elevation, sometimes combined with ice and snow cover, results in low light intensities in the water column and hence in low phytoplankton growth rates. The vigorous turbulent mixing that normally occurs either in winter and early spring or (in the case of icecovered lakes) after the ice has thawed also affects the availability of light to the phytoplankton. In spring, lake phytoplankton communities are typically dominated by fast-growing species that are adapted to steep light and temperature gradients, and are thus particularly responsive to the physical conditions that occur at this time of year (Adrian et al., 2006). By contrast, physical conditions during summer (high temperatures and high light availability) are much closer to those required for optimum growth, so that population dynamics are increasingly influenced by other factors, such as nutrient limitation or biotic interactions (Sommer et al., 1986; Straile, 2005). Moreover, during summer, slowly growing zooplankton species with longer and more complex life cycles are often quite abundant. Because these species can be affected by multiple warming events in the course of a year, their response to environmental changes tends to be more species-specific (Adrian et al., 2006; Blenckner et al., 2007). Hence, in temperate lakes biological variables are more likely to show coherence during winter and spring than during the rest of the year. In the following we will discuss examples of coherence in phytoplankton (see also Chapter 14 of this volume), zooplankton, and fish.

Phytoplankton growth during winter and early spring is severely light limited (Tulonen et al., 1994). Intrinsically low incident light levels can be further reduced within the water column by ice and snow cover (Adrian et al., 1999; Weyhenmeyer 
et al., 1999), while vigorous, penetrative turbulent mixing will reduce light availability for phytoplankton in deep lakes (Peeters et al., 2007). Consequently, the timing of the phytoplankton spring bloom in ice-covered lakes might also exhibit coherence if the timing of ice-off shows a coherent response to climatic forcing. The timing of the spring phytoplankton bloom in Müggelsee, Germany, and Erken, Sweden, has been shown to depend on the timing of ice-off and on the NAO (Adrian et al., 1999; Weyhenmeyer et al., 1999; Gerten and Adrian, 2000), suggesting the existence of coherence in phytoplankton phenology over large distances. However, no coherence in spring phytoplankton bloom dynamics was observed between Müggelsee, in northern Germany, and Lake Constance, in southern Germany (Straile and Adrian, 2000), as the mechanisms controlling the onset of the spring bloom-i.e., the timing of ice-off (Müggelsee) and the timing of the onset of stratification (Lake Constance) - differed between the lakes.

Studies on Sweden's largest lakes (Vänern, Vättern and Mälaren), and in much smaller Lake Erken, have shown a tendency towards an earlier spring phytoplankton bloom and earlier nutrient depletion (of up to one month) in all lakes as winter air temperatures have increased (Weyhenmeyer et al., 1999; Weyhenmeyer, 2001). In Sweden's largest lakes the total phytoplankton biomass from May to October showed no coherent change, but the spring and summer biomass of phytoplankton groups such as cyanobacteria and chlorophytes increased coherently among the lakes as air temperatures increased. After the especially mild winter of 1988/1989, an increase in cyanobacterial biomass was found throughout Europe (Weyhenmeyer et al., 2002). Considering that some of the cyanobacterial species that dominate in these lakes in summer can be toxic, the large-scale, coherent effect of warmer winters on phytoplankton is potentially far-reaching.

Changes in the structure of the phytoplankton community can also be coherent, as indicated by a multivariate study of phytoplankton species composition in five, mainly deep, perialpine lakes; viz. Lower Lake Zurich, Upper Lake Zurich, the Lake of Walenstadt (Walensee), Lake Geneva and Lake Constance (Anneville et al., 2004, 2005). Trophic status and local environmental conditions are different among the lakes, and the phytoplankton assemblages found in the lakes are also different. Nevertheless, the patterns of occurrence of some phytoplankton assemblages were found to be strongly synchronous on annual to decadal time-scales. This longterm regional coherence sometimes involves different phytoplankton assemblages. Although the composition of the phytoplankton in these lakes was strongly influenced by the long-term reduction in phosphorus loading, changes in seasonal meteorological forcing were also found to have induced synchronous changes in the phytoplankton assemblages. These results provide evidence that synchronous longterm changes in the phytoplankton communities of geographically distant lakes can occur despite there having been no synchrony in overall biomass changes.

While the phytoplankton coherence observed in these lakes was due mainly to a coherent decline in nutrient concentrations, statistical analysis also suggested the existence of a link between community structure and the winter NAO. Surprisingly, even summer phytoplankton communities exhibited a coherent response to climatic forcing in these lakes, but the mechanisms responsible for this are not yet clear 
(Anneville et al., 2005). In Esthwaite Water and Blelham Tarn, two productive lakes in the English Lake District, the key factor responsible for the observed coherence in the summer abundance of the zooplankton proved easier to identify (George et al., 2000). Here, it was the mixing events that entrained nutrients from the deep water and stimulated the growth of edible algae that were found to be critical.

The rates of physiological processes in ectothermal organisms are strongly influenced by ambient temperatures. Consequently, the growth and reproduction rates of zooplankton species will be limited by low temperatures during winter and spring. As coherence in the timing of the spring increase in water temperature is high on regional and even supra-regional scales, we might expect coherence in zooplankton growth on similar spatial scales to occur during spring. Despite great limnological differences between Müggelsee and Lake Constance, the growth of a key herbivorous zooplankter, Daphnia, was indeed found to be highly coherent in these two lakes, and in both cases was related to the winter NAO (Straile and Adrian, 2000). Furthermore, the timing of the clear-water phase-i.e., the timing of maximum water transparency during early summer due to Daphnia grazing - was also found to be coherent (Straile and Adrian, 2000). Subsequent studies in a number of European lakes demonstrated the existence of similar links between the winter NAO and the spring biomass of Daphnia, the timing of the Daphnia spring peak and the timing of the clear-water phase: for example, the observations by Scheffer et al. (2001) in a suite of Dutch lakes, by Straile (2002) in central Europe, by Anneville et al. (2002) in Lake Geneva and by Wagner and Benndorf (2007) in Lake Bautzen in Germany.

There have been very few coherence studies on aquatic invertebrates and fish. However, George (2000) and Elliott et al. (2000) have shown that the times of emergence of alder flies and sea trout fry in the English Lake District are correlated with the NAO. The most comprehensive study of coherence in the spawning time of fish is that of Nõges and Järvet (2005) in Estonia. Their analysis was based on observations conducted over a period of 40 years (1951-1990) at 148 stations in the region of Estonia which includes the two largest lakes in the country; viz. Võrtsjärv and Peipsi. In both lakes, a coherent, long-term shift in the timing of spawning of bream (Abramis brama) was found ( 10 days earlier over the 40 -year period) that tended to compensate for the long-term increase in water temperature. By contrast, the timing of the spawning of roach (Rutilus rutilus) was approximately constant regardless of the long-term increase in water temperature. However, interannual fluctuations in the spawning date of roach tended to occur coherently between the lakes, although there was no long-term shift. No evidence was found of coherent interannual fluctuations in the spawning date of bream. As the earlier spawner, roach is presumably influenced more strongly by the more coherent early spring changes in lakes, while the potential for coherence in interannual fluctuations disappears by the time of spawning of bream (on average 16-17 days later than roach).

Thus ecological responses to fluctuations in climate can occur coherently over large spatial scales provided that physical forcing is coherent and also rate-limiting. Given these prerequisites, coherent behaviour can be observed in the phenology of life-cycle events and in the interactions that regulate the dynamics of food webs in many aquatic systems. 


\subsection{Long-Term Supra-Regional Coherence}

In the above sections, we have presented examples that demonstrate the existence of spatial coherence in limnological variables on regional scales; i.e., from about ten kilometres up to several hundred kilometres. However, climate-driven spatial coherence exists on even larger scales. For example, Benson et al. (2000) compared time-series of temperature from lakes in four lake districts in central North America that are separated by up to $1,300 \mathrm{~km}$, and found strong coherence in nearsurface temperatures and epilimnetic temperatures (but much weaker coherence in hypolimnetic temperatures). In a study of coherence in various lake variables within and among regions on the Canadian Boreal Shield, Arnott et al. (2003) also found significant supra-regional coherence in near-surface temperatures, but much more heterogeneity in $\mathrm{pH}$ and in the biomass and richness of phytoplankton and zooplankton. In Europe, a recent extensive study (Blenckner et al., 2007) explored the spatial coherence in the response of a suite of physical, chemical and biological variables to climatic forcing on spatial scales exceeding $\sim 1000 \mathrm{~km}$. Because of the well-established influence of the NAO on many European lakes, they used a metaanalysis approach to summarise the observed correlations between the selected limnological variables and indices of the winter NAO. Results were collated from 7 lakes in northern Europe (Estonia, Finland and Sweden), 7 lakes in central Europe (Austria, Germany and Switzerland) and 4 lakes in western Europe (the United Kingdom and Ireland). Not unexpectedly, they found the strongest response to the winter NAO was exhibited by lake water temperatures, especially by the surface water temperature. Again not unexpectedly in view of previous work on individual lakes, winter nitrate concentrations also showed a strongly coherent response to the winter NAO, with concentrations tending to be high in positive NAO years and low in negative NAO years. Notable exceptions were the lakes of the English Lake District, where nitrate concentrations were lower in positive NAO years, when more nitrate was assimilated in the soils of the surrounding catchments. This difference had already been noted in an earlier study of the correlations observed between the detrended winter nitrate concentrations in Finland and the UK and the NAO (George et al., 2004a). In Finland, the correlation with the NAO was negative and clearly related to the timing of snow melt. In the UK, the correlation was negative and closely correlated with the winter air temperature. Blenckner et al. (2007) also noted a tendency for the concentrations of soluble reactive phosphorus and soluble reactive silicate to be negatively correlated with the winter NAO. The authors suggested that this behaviour may be related to large-scale coherent interannual fluctuations in the phenology of the spring phytoplankton bloom, but the response did not appear to depend on the trophic status of the lakes. Interannual fluctuations in winter and spring concentrations of total phosphorus were also related to the winter NAO, with low values in positive NAO years and high values in negative NAO years. However, the winter and spring phytoplankton biomass showed no coherent relationship to the winter NAO. By contrast, the abundance of daphnids in winter and spring was found to fluctuate coherently with the winter NAO, although lake-to-lake variability was high. Calanoid copepods showed no overall coherent 
relationship to the winter $\mathrm{NAO}$, but the summer abundance of cyclopoid copepods was significantly higher in positive NAO years than in negative NAO years, possibly as a result of coherent fluctuations in the timing of their emergence from resting stages.

\subsection{Conclusions}

In this chapter we have summarised the results of studies designed to investigate the degree of short-term and long-term coherence apparent on regional and supraregional scales among lakes and rivers in Europe. These results allow us to answer the original question posed in Fig. 17.2; viz. 'Are local effects strong enough to destroy the coherence imparted by the climate?' In general the answer is quite clearly no. Although the meteorological variables that ultimately govern much of the dynamic behaviour of lakes and rivers act locally, these forcing variables often exhibit a high degree of coherence over a range of spatial and temporal scales. Coherence in the behaviour of the driving meteorological variables will almost invariably result in a degree of coherence in the response of water bodies forced by these variables. Local effects, both external and internal to the water body, add noise to the climate signal, but the magnitude of the observed coherence present allows us to reject the hypothesis that surface water bodies respond merely as idiosyncratic individuals to climate forcing. From the point of view of climate impact research, surface water bodies can be regarded conceptually as local samples of a climaticallydriven continuum.

For lakes, spatial coherence is, not surprisingly, highest for physical variables measured at the lake surface. Short-term coherence in lakes is essentially confined to water temperatures in the uppermost part of the water column. On interannual to interdecadal time-scales, the timing of ice-out, the temperatures of rivers, streams and lake surfaces and the discharge rates of streams are all directly influenced by regional climatic forcing. They consequently exhibit a high degree of coherence that is linked to the regional-scale spatial homogeneity of the relevant meteorological driving variables. Air temperature, which exhibits the highest degree of spatial homogeneity, is responsible for much, but not all, of the observed coherence. Since air temperatures in much of Europe in winter and spring are strongly influenced by the climate prevailing over the North Atlantic, it is not surprising that physical lake surface and river variables at these times of year are strongly linked to the NAO. As the NAO affects a number of meteorological driving variables, its influence on lakes is typically greater than that of any single variable.

Water temperatures below the thermocline are invariably less coherent from lake to lake, since they are strongly influenced by the mixing characteristics of the individual lakes. However, because the physical (and chemical) characteristics of the hypolimnion are determined to a large degree during spring turnover, the weather conditions prevailing during turnover often leave their signature in the deeper water for a considerable length of time. As the climate in northern and western Europe at 
this time of year is often strongly influenced by the NAO, this implies that a coherent NAO signal can persist for some time in the deep water.

Coherent behaviour in nutrient concentrations appears to be strongest in the case of nitrate, which often exhibits an interannual variability linked to the NAO. Concentrations of soluble reactive phosphorus appear to be influenced by the climate to a much lesser extent, but may exhibit some decadal-scale coherence related to anthropogenic effects. Coherence in biological variables is typically very much weaker, but coherent patterns are frequently reported in derived variables that reflect the timing of biological events; e.g., the timing of the spring bloom and the clear-water phase.

Acknowledgements The CLIME project was supported under contract EVK1-CT-2002-00121 by the 5th EU Framework Programme for Research and Technological Development. The participation of DML and REH was made possible by funding from the Swiss Federal Office for Education and Science. The authors gratefully acknowledge all individuals and institutes involved in collecting the data on which this chapter is based.

\section{References}

Adrian, R., Walz, N., Hintze, T., Hoeg, S. and Rusche, R. (1999) Effects of ice duration on the plankton succession during spring in a shallow polymictic lake, Freshwater Biology 41, 621-623.

Adrian, R., Wilhelm, S. and Gerten, D. (2006) Life-history traits of lake plankton species may govern their phenological response to climate warming, Global Change Biology 12, 652-661. doi: $10.1111 /$ j. $1365-2486.2006 .01125 . x$

Anneville, O., Gammeter, S. and Straile, D. (2005) Phosphorus decrease and climate variability: mediators of synchrony in phytoplankton changes among European peri-alpine lakes, Fresh water Biology 50, 1731-1745.

Anneville, O., Soussi, S., Gammeter, S. and Straile, D. (2004) Seasonal and inter-annual scales of variability in phytoplankton assemblages: comparison of phytoplankton dynamics in three peri-alpine lakes over a period of 28 years, Freshwater Biology 49, 98-115.

Anneville, O., Soussi, S., Ibañez, F., Ginot, V., Druart, J.-C. and Angeli, N. (2002) Temporal mapping of phytoplankton assemblages in Lake Geneva: annual and interannual changes in their patterns of succession, Limnology and Oceanography 47, 1355-1366.

Arnott, S. E., Keller, B., Dillon, P. J., Yan, N., Paterson, M. and Findlay, D. (2003) Using temporal coherence to determine the reponse to climate change in Boreal Shield lakes, Environmental Monitoring and Assessment 88, 365-388.

Arvola, L., Räike, A., Kortelainen, P. and Järvinen, M. (2004) The effect of climate and landuse on TOC concentrations and loads in Finnish rivers, Boreal Environment Research 9, 381-387.

Baines, S. B., Webster, K. E., Kratz, T. K., Carpenter, S. R. and Magnuson, J. J. (2000) Synchronous behavior of temperature, calcium, and chlorophyll in lakes of northern Wisconsin, Ecology 81, $815-825$.

Battarbee, R. W., Patrick, S., Kernan, M., Psenner, R., Thies, H., Grimalt, J., Rosseland, B.-O., Wathne, B., Catalan, J., Mosello, R., Lami, A., Livingstone, D. M., Stuchlík, E., Straškrabova, V. and Raddum, G. (2005) High mountain lakes and atmospherically transported pollutants, In: U. M. Huber, H. K. M. Bugmann and M. A. Reasoner (eds.), Global change and mountain regions: an overview of current knowledge, Springer, New York, Advances in Global Change Research Volume 23, pp. 113-121.

Behrendt, H. and Stellmacher, R. (1987) Long-term changes in water quality parameters of a shallow eutrophic lake and their relations to meteorologic and hydrologic elements, in The 
influence of climate change and climatic variability on the hydrologic regime and water resources, Proceedings of the Vancouver Symposium, August 1987, IAHS Publication No. 168, pp. 535-544.

Benson, B. J., Lenters, J. D., Magnuson, J. J., Stubbs, M., Kratz, T. K., Dillon, P. J., Hecky, R. E. and Lathrop, R. C. (2000) Regional coherence of climatic and lake thermal variables of four lake districts in the Upper Great Lakes Region of North America, Freshwater Biology 43, 517-527.

Blenckner, T., Adrian, R., Livingstone, D. M., Jennings, E., Weyhenmeyer, G. A., George, D. G., Jankowski, T., Järvinen, M., Nic Aonghusa, C., Nõges, T., Straile, D. and Teubner, K. (2007) Large-scale climatic signatures in lakes across Europe: a meta-analysis, Global Change Biology 13(7), 1314-1326. doi: 10.1111/j.1365-2486.2007.01364.x

Blenckner, T., Järvinen, M. and Weyhenmeyer, G. A. (2004) Atmospheric circulation and its impact on ice phenology in Scandinavia, Boreal Environment Research 9, 371-380.

Bradley, D. C. and Ormerod, S. J. (2001) Community persistence among stream invertebrates tracks the North Atlantic Oscillation, Journal of Animal Ecology 70, 987-996.

Davies, J. J. L., Jenkins, A., Monteith, D. T., Evans, C. D. and Cooper, D. M. (2005) Trends in surface water chemistry of acidified UK Freshwaters, 1988-2002, Environmental Pollution 137, 27-39.

Doganovsky, A. M. and Myakisheva, N. V. (2000) The water level in Lake Ladoga in different frequency ranges, In: A. Peltonen, E. Grönlund and M. Viljanan (eds.), Proceedings of the Third International Lake Ladoga Symposium 1999, University of Joensuu, Publications of Karelian Institute No. 129, Joensuu, Finland, pp. 374-377.

Dokulil, M. T, Jagsch, A., George, G. D., Anneville, O., Jankowski, T., Wahl, B., Lenhart, B., Blenckner, T. and Teubner, K. (2006) Twenty years of spatially coherent deepwater warming in lakes across Europe related to the North Atlantic Oscillation, Limnology and Oceanography 51(6), 2787-2793.

Eckel, O. (1955) Statistisches zur Vereisung der Ostalpenseen, Wasser und Leben 7, 49-57.

Edinger, J. E., Duttweiler, D. W. and Geyer, J. C. (1968) The response of water temperatures to meteorological conditions, Water Resources Research 4, 1137-1143.

Elliott, J. M., Hurley, M. H. and Maberly, S. C. (2000) The emergence period of sea-trout fry in a Lake District stream correlates with the North Atlantic Oscillation, Journal of Fish Biology 56, 208-210.

George, D. G. (2000) Using climate indicators to monitor patterns of change in freshwater lakes and reservoirs, In: J. A. A. Jones, K. Gilman, A. Jigorel and J. H. Griffin (eds.), Water in the Celtic World: Managing Resources for the 21st Century, British Hydrological Society, Occasional Paper No. 11, pp. 93-102.

George, D. G., Järvinen, M. and Arvola, L. (2004a) The influence of the North Atlantic Oscillation on the winter characteristics of Windermere (UK) and Päajärvi (Finland), Boreal Environment Research 9, 389-399.

George, D. G., Maberly, S. C. and Hewitt, D. P. (2004b) The influence of the North Atlantic Oscillation on the physical, chemical and biological characteristics of four lakes in the English Lake District. Freshwater Biology 49, 760-774.

George, D. G., Talling, J. F. and Rigg, E. (2000) Factors influencing the temporal coherence of five lakes in the English Lake District, Freshwater Biology 43, 449-461.

Gerten, D. and Adrian, R. (2000) Climate-driven changes in spring plankton dynamics and the sensitivity of shallow polymictic lakes to the North Atlantic Oscillation. Limnology and Oceanography 45, 1058-1066.

Gerten, D. and Adrian, R. (2001) Differences in the persistency of the North Atlantic Oscillation signal among lakes, Limnology and Oceanography 46, 448-455.

Goudsmit, G.-H., Lemcke, G., Livingstone, D. M., Lotter, A. F., Müller, B. and Sturm, M. (2000) Hagelseewli: a fascinating mountain lake - suitable for palæoclimate studies? Verhandlungen der Internationalen Vereinigung für Theoretische und Angewandte Limnologie 27(2), 1013-1022. 
Hänninen, J., Vuorinen, I. and Hjelt, P. (2000) Climatic factors in the Atlantic control the oceanographic and ecological changes in the Baltic Sea, Limnology and Oceanography 45, 703-710.

Hari, R. E., Livingstone, D. M., Siber, R., Burkhardt-Holm, P. and Güttinger, H. (2006) Consequences of climatic change for water temperature and brown trout populations in Alpine rivers and streams, Global Change Biology 12, 10-26. doi: 10.1111/j.1365-2486.2005.01051.x

Hurrell, J. W. (1995) Decadal trends in the North Atlantic Oscillation: regional temperatures and precipitation, Science 269, 676-679.

Jaani, A. (1973) Veerohkus muutub tsükliliselt, Eesti Loodus 12, 758-764.

Jankowski, T., Livingstone, D. M., Forster, R. and Bührer, H. (2005) Long-term nitrate concentrations in five perialpine lakes: regional coherence, Verhandlungen der Internationalen Vereinigung für Theoretische und Angewandte Limnologie 29(2), 927-931.

Järvinen, M., Rask, M., Ruuhijärvi, J. and Arvola, L. (2002) Temporal coherence in water temperature and chemistry under the ice of boreal lakes (Finland), Water Research 36, 3949-3956.

Jennings, E. and Allott, N. (2006) Position of the Gulf Stream influences lake nitrate concentrations in SW Ireland, Aquatic Sciences 68, 482-489.

Jennings, E., Allott, N., McGinnity, P., Poole, R., Quirke, W., Twomey, H. and George, D. G. (2000) The North Atlantic Oscillation; effects on freshwater systems in Ireland, Biology and Environment: Proceedings of the Royal Irish Academy 100B, 149-157.

Jones, P. D., Osborn, T. J. and Briffa, K. R. (1997) Estimating sampling errors in large-scale temperature averages, Journal of Climate 10, 2548-2568.

Kettle, H., Thompson, R., Anderson, N. J. and Livingstone, D. M. (2004) Empirical modeling of summer lake surface water temperatures in southwest Greenland, Limnology and Oceanography 49(1), 271-282.

Kiely, G. (1999) Climate change in Ireland from precipitation and streamflow observations, Advances in Water Research 23, 141-151.

Kratz, T. K., Soranno, P. A., Baines, S. B., Benson, B. J., Magnuson, J. J., Frost, T. M. and Lathrop, R. C. (1998) Inter-annual synchronous dynamics in north temperate lakes in Wisconsin, USA In: D. G. George, J. C. Jones, P. Puncochar, D. S. Reynolds and D. W. Sutcliffe (eds.), Management of lakes and reservoirs during global climate change, Kluwer Academic Publishers, The Netherlands, pp. 273-287.

Livingstone, D. M. (1993) Temporal structure in the deep-water temperature of four Swiss lakes: a short-term climatic change indicator? Verhandlungen der Internationalen Vereinigung für Theoretische und Angewandte Limnologie 25(1), 75-81.

Livingstone, D. M. (1997) An example of the simultaneous occurrence of climate-driven "sawtooth" deep-water warming/cooling episodes in several Swiss lakes, Verhandlungen der Internationalen Vereinigung für Theoretische und Angewandte Limnologie 26(2), 822-826.

Livingstone, D. M. (1999) Ice break-up on southern Lake Baikal and its relationship to loca and regional air temperatures in Siberia and to the North Atlantic Oscillation, Limnology and Oceanography 44(6), 1486-1497.

Livingstone, D. M. (2000) Large-scale climatic forcing detected in historical observations of lake ice break-up, Verhandlungen der Internationalen Vereinigung für Theoretische und Angewandte Limnologie 27(5), 2775-2783.

Livingstone, D. M. (2008) A change of climate provokes a change of paradigm: taking leave of two tacit assumptions about physical lake forcing. International Review of Hydrobiology 93 (4-5), 404-414.

Livingstone, D. M. and Dokulil, M. T. (2001) Eighty years of spatially coherent Austrian lake surface water temperatures and their relationship to regional air temperature and the North Atlantic Oscillation, Limnology and Oceanography 46(5), 1220-1227.

Livingstone, D. M. and Hari, R. E. (2008) Coherence in the response of river and lake temperatures in Switzerland to short-term climatic fluctuations in summer, Verhandlungen der Internationalen Vereinigung für Theoretische und Angewandte Limnologie 30(3), 449-454.

Livingstone, D. M. and Kernan, M. (2009) Regional coherence and geographical variability in the surface water temperatures of Scottish Highland lochs, Advances in Limnology 62, $349-360$. 
Livingstone, D. M. and Lotter, A. F. (1998) The relationship between air and water temperatures in lakes of the Swiss Plateau: a case study with palæolimnological implications, Journal of Paleolimnology 19(2), 181-198.

Livingstone, D. M. and Padisák, J. (2007) Large-scale coherence in the response of lake surface water temperatures to synoptic-scale climate forcing during summer, Limnology and Oceanography 52(2), 896-902.

Livingstone, D. M., Jankowski, T. and Lotter, A. F. (2005b) Patterns of deviation from linearity in the relationship between lake surface temperature and altitude above sea level in the Swiss Alps, Verhandlungen der Internationalen Vereinigung für Theoretische und Angewandte Limnologie 29(1), 300-305.

Livingstone, D. M., Lotter, A. F. and Walker, I. R. (1999) The decrease in summer surface water temperature with altitude in Swiss Alpine lakes: a comparison with air temperature lapse rates, Arctic Antarctic and Alpine Research 31(4), 341-352.

Lloret, J., Lleonart, J., Solé, I. and Fromentin, J. M. (2001) Fluctuations of landings and environmental conditions in the north-western Mediterranean Sea, Fisheries Oceanography 10, $33-50$.

Magnuson, J. J., Benson, B. J. and Kratz, T. K. (1990) Temporal coherence in the limnology of a suite of lakes in Wisconsin, USA, Freshwater Biology 23, 145-149.

Magnuson, J. J., Benson, B. J. and Kratz, T. K. (2004) Patterns of coherent dynamics within and between lake districts at local to intercontinental scales, Boreal Environment Research 9 , 359-369.

Magnuson, J. J., Benson, B. J., Lenters, J. D. and Robertson, D. M. (2006b) Climate-driven variability and change, In: J. J. Magnuson, T. K. Kratz and B. J. Benson (eds.), Long-term dynamics of lakes in the landscape: long-term ecological research on north temperate lakes, Oxford University Press, Oxford, UK, pp. 123-150.

Magnuson, J. J., Kratz, T. K., Benson, B. J. and Webster, K. E. (2006a) Coherent dynamics among lakes, In: J. J. Magnuson, T. K. Kratz and B. J. Benson (eds.), Long-term dynamics of lakes in the landscape: long-term ecological research on north temperate lakes, Oxford University Press, Oxford, UK, pp. 89-106.

Matuszek, J. E., and Shuter, B. J. (1996) An empirical method for the prediction of daily water temperatures in the littoral zone of temperate lakes, Transactions of the American Fisheries Society 125, 622-627.

McCombie, A. M. (1959) Some relations between air temperatures and the surface water temperature of lakes, Limnology and Oceanography 4, 252-258.

Monteith, D. T., Evans, C. D. and Reynolds, B. (2000) Are temporal variations in the nitrate content of UK upland freshwaters linked to the North Atlantic Oscillation? Hydrological Processes 14, $1745-1749$.

Nõges, P. and Järvet, A. (2005) Climate driven changes in the spawning of roach (Rutilus rutilus (L.)) and bream (Abramis brama (L.)) in the Estonian part of the Narva River basin, Boreal Environment Research 10, 45-55.

Nõges, T. and Nõges, P. (2004) Large shallow temperate lakes Peipsi and Võrtsjärv: consequences of eutrophication and climate change, In: P. Wassmann and K. Olli (eds.), Drainage basin nutrient inputs and eutrophication: an integrated approach, University of Troms $\emptyset$, Norway, pp. 290-301, available at www.ut.ee/ olli/eutr/

Nõges, T., Nõges, P. and Laugaste, R. (2003) Water level as the mediator between climate change and phytoplankton composition in a large shallow temperate lake, Hydrobiologia 506(1-3), 257-263.

Palecki, M. A. and Barry, R. G. (1986) Freeze-up and break-up of lakes as an index of temperature changes during the transition seasons: a case study for Finland, Journal of Climate and Applied Meteorology 25, 893-902.

Peeters, F., Straile, D., Lorke, A. and Ollinger, D. (2007) Turbulent mixing and phytoplankton spring bloom development in a deep lake, Limnology and Oceanography 52, 286-298.

Rodionov, S. N. (1994) Global and regional climate interaction: the Caspian Sea experience, Kluwer, Dordrecht, $241 \mathrm{pp}$. 
Rusak, J. A., Yan, N. D., Somers, K. M. and McQueen, D. J. (1999) The temporal coherence of zooplankton population abundances in neighbouring north-temperate lakes, American Naturalist 153, 46-58.

Salonen, K., Arvola, L. and Rask, M. (1984) Autumnal and vernal circulation of small forest lakes in southern Finland, Verhandlungen der Internationalen Vereinigung fïr. Theoretische und Angewandte Limnologie 22, 103-107.

Scheffer, M., Straile, D., van Nes, E. H. and Hosper, H. (2001) Climatic warming causes regime shifts in lake food webs, Limnology and Oceanography 46, 1780-1783.

Schindler, D. W., Beaty, K. G., Fee, E. J., Cruikshank, D. R., DeBruyn, E. R., Findlay, D. L., Linsey, G. A., Shearer, J. A., Stainton, M. P and Turner, M. A. (1990) Effects of climatic warming on lakes of the central boreal forest, Science 250, 967-970.

Shuter, B. J., Schlesinger, D. A. and Zimmerman, A. P. (1983) Empirical predictors of annual surface water temperature cycles in North American lakes, Canadian Journal of Fisheries and Aquatic Science 40, 1838-1845.

Sommer, U., Gliwicz, Z. M., Lampert, W. and Duncan, A. (1986) The PEG-model of seasonal succession of planktonic events in fresh waters, Archiv für Hydrobiologie 106, 433-471.

Šporka, F., Livingstone, D. M., Stuchlík, E., Turek, J. and Galas, J. (2006) Water temperatures and ice cover in the lakes of the Tatra Mountains, Biologia 61(Suppl. 18), S77-S90.

Stewart, K. M. and Haugen, R. K. (1990) Influence of lake morphometry on ice dates, Verhandlungen der Internationalen Vereinigung für Theoretische und Angewandte Limnologie 24, $122-127$.

Straile, D. (2002) North Atlantic Oscillation synchronizes food-web interactions in central European lakes, Proceedings of the Royal Society of London B 269, 391-395.

Straile, D. (2005) Food webs in lakes - seasonal dynamics and the impact of climate variability, In: A. Belgrano, U. Scharler, J. Dunne and R. E. Ulanowicz (eds.), Aquatic food webs: an ecosystem approach, Oxford University Press, Oxford, UK, pp. 41-50.

Straile, D. and Adrian, R. (2000) The North Atlantic Oscillation and plankton dynamics in two European lakes - two variations on a general theme, Global Change Biology 6, 663-670.

Straile; D., Jöhnk, K. and Rossknecht, H. (2003a) Complex effects of winter warming on the physicochemical characteristics of a deep lake, Limnology and Oceanography 48(4), 1432-1438.

Straile, D., Livingstone, D. M., Weyhenmeyer, G. A. and George, D. G. (2003b) The response of freshwater ecosystems to climate variability associated with the North Atlantic Oscillation, In: J: W. Hurrell, Y. Kushnir, G. Ottersen and M. Visbeck (eds.), The North Atlantic Oscillation: climate significance and environmental impact, American Geophysical Union, Geophysical Monograph Series Volume 134, pp. 263-279.

Sweers, H. H. (1976) A nomogram to estimate the heat-exchange coefficient at the air-water interface as a function of wind speed and temperature; a critical survey of some literature, Journal of Hydrology 30, 375-401.

Tulonen, T., Kankaala, P., Ojala, A. and Arvola, L. (1994) Factors controlling production of phytoplankton and bacteria under ice in a humic, boreal lake, Journal of Plankton Research 16 $1411-1432$.

Wagner, A. and Benndorf, J. (2007) Climate-driven warming during spring destabilises a Daphniapopulation: a mechanistic food web approach, Oecologia doi:10.1007/s00442-006-0554-5.

Webb, M. S. (1974) Surface temperatures of Lake Erie, Water Resources Research 10, 199-210.

Weyhenmeyer, G. A. (2001) Warmer winters: are planktonic algal populations in Sweden's largest lakes affected? Ambio 30, 565-571.

Weyhenmeyer, G. A. (2004) Synchrony in relationships between the North Atlantic Oscillation and water chemistry among Sweden's largest lakes, Limnology and Oceanography 49(4), 1191-1201.

Weyhenmeyer, G. A., Adrian, R., Gaedke, U., Livingstone, D. M. and Maberly, S. C. (2002) Response of phytoplankton in European lakes to a change in the North Atlantic Oscillation, 
Verhandlungen der Internationalen Vereinigung für Theoretische und Angewandte Limnologie 28(3), 1436-1439.

Weyhenmeyer, G. A., Blenckner, T. and Pettersson, K. (1999) Changes of the plankton spring outburst related to the North Atlantic Oscillation, Limnology and Oceanography 44, $1788-1792$.

Weyhenmeyer, G. A., Jeppesen, E., Adrian, R., Arvola, L., Blenckner, T., Jankowski, T., Jennings, E., Jensen, J. P., Nõges, P., Nõges, T. and Straile, D. (2007) Nitrogen-depleted conditions on the increase in shallow northern European lakes, Limnology and Oceanography 52(4), 1346-1353.

Weyhenmeyer, G. A., Meili, M. and Livingstone, D. M. (2004) Nonlinear temperature response of lake ice breakup, Geophysical Research Letters 31(7), L07203, doi:10.1029/2004GL019530.

Wilhelm, S., Hintze, T., Livingstone, D. M. and Adrian, R. (2006) Long-term response of daily epilimnetic temperature extrema to climate forcing, Canadian Journal of Fisheries and Aquatic Science 63(11), 2467-2477.

Yoo, J. and D'Odorico, P. (2002) Trends and fluctuations in the dates of ice break-up of lakes and rivers in Northern Europe: the effect of the Northern Oscillation, Journal of Hydrology 268, $100-112$. 